\title{
Penerapan Model Pembelajaran Kooperatif Tipe Student Team Achievement Division (STAD) untuk Meningkatkan Hasil Belajar PAl Siswa pada Materi Mengenal Para Rasul-Rasul Allah SWT di kelas V SDN. No. 026/XI Cempaka Tahun 2016/2017
}

\author{
Maili Asniar ${ }^{1}$ \\ ${ }^{1}$ Guru SDN. No. 026/XI Cempaka, Kecamatan Hamparan Rawang, Kota Sungai Penuh, Provinsi Jambi \\ e-mail: maili.asniar02@gmail.com
}

\begin{abstract}
This study aims to improve the learning outcomes of fifth grade students of SDN. No. 026 / XI Cempaka in $2016 / 2017$ in Islamic Education subjects using the cooperative learning model Student Team Achievement Division (STAD) type. This research was conducted at SDN. No. 026 / XI Cempaka in 2016/2017, Hamparan Rawang District, Sungai Penuh City, Jambi Province. The study was conducted from January to April 2017. This study involved eight class V students. Class action research was conducted in two cycles. Each cycle is conducted in two meetings with four activities, namely planning, implementation, observation, and reflection. Data collected in the form of learning outcomes data collected by tests and observations. The data is then processed by a simple statistical test that is by calculating the class average value and the percentage of mastery learning. The results of the study showed that the use of the STAD cooperative learning model could improve the learning outcomes of fifth grade students of SDN. No. 026/XI Cempaka in 2016/2017 on the subjects of Islamic Education. The average value of students who initially 53.13 increased to 63.75 in Cycle I, and again increased to 75.00 in Cycle II. The percentage of students' mastery learning increased which initially $37.50 \%$ increased to $62.50 \%$ in Cycle I and again increased to $100.00 \%$ in Cycle II. Thus, the STAD type cooperative learning model can be an alternative for teachers to improve student learning outcomes in Islamic Education subjects.
\end{abstract}

Keywords: classroom action research, elementary school, Islamic education, learning outcomes, STAD

\section{PENDAHULUAN}

Agama memiliki peran yang amat penting dalam kehidupan umat manusia. Agama menjadi pemandu dalam upaya mewujudkan suatu kehidupan yang bermakna, damai dan bermartabat. Menyadari betapa pentingnya peran agama bagi kehidupan umat manusia maka internalisasi nilai-nilai agama dalam kehidupan setiap pribadi menjadi sebuah keniscayaan, yang ditempuh melalui pendidikan baik pendidikan di lingkungan keluarga, sekolah maupun masyarakat.

Pendidikan Agama dimaksudkan untuk peningkatan potensi spiritual dan membentuk peserta didik agar menjadi manusia yang beriman dan bertakwa kepada Tuhan Yang Maha Esa dan berakhlak mulia. Akhlak mulia mencakup etika, budi pekerti, dan moral sebagai perwujudan dari pendidikan Agama. Peningkatan potensi spritual mencakup pengenalan, pemahaman, dan penanaman nilai-nilai keagamaan, serta pengamalan nilai-nilai tersebut dalam kehidupan individual ataupun kolektif kemasyarakatan. Peningkatan potensi spritual tersebut pada akhirnya bertujuan pada optimalisasi berbagai potensi yang dimiliki manusia yang aktualisasinya mencerminkan harkat dan martabatnya sebagai makhluk Tuhan.

Mata pelajaran Pendidikan Agama Islam menjadi mata pelajaran wajib yang harus diikuti oleh siswa sejak sekolah dasar hingga perguruan tinggi. Mata Pelajaran Pendidikan Agama Islam memiliki mandate untuk membentuk warga negara yang memahami dan mampu melaksanakan hak-hak dan kewajibannya untuk menjadi warga negara Indonesia yang cerdas, terampil, dan berkarakter sesuai dengan yang diamanatkan oleh Pancasila dan UUD 1945. Dengan demikian, siswa harus mampu memahami materi yang disajikan dalam mata pelajaran tersebut.

Untuk mencapai tujuan dati Pendidikan Agama Islam di sekolah, guru diharapkan mampu melaksanakan kegiatan pembelajaran dengan baik. Dalam melaksanakan kegiatan pembelajaran, guru menemukan masalah, salah satunya adalah hasil belajar siswa yang rendah. Misalnya, Jamiati (2011) menemukan masalah dalam pembelajaran Pendidikan Agama Islam di SDN 040 Salo Kecamatan Salo Kabupaten Kampar, yaitu hasil belajar yang diperoleh murid belum optimal, hal ini terlihat dari nilai rapor khususnya pada mata pelajaran Pendidikan Agama Islam. Lebih dari $60 \%$ dari seluruh murid yang belum mencapai nilai kriteria ketuntasan minimal (KKM) 70 yang ditetapkan, murid terkesan sulit memahami materi yang disampaikan oleh guru dikelas, hal ini terlihat bahwa lebih dari $65 \%$ murid jarang menjawab pertanyaan yang diberikan oleh gurunya, dari tugas atau PR yang diberikan guru, hanya $10 \%$ hingga $38 \%$ yang dapat mengerjakan PR dengan benar dan sisanya masih banyak terdapat kesalahan, dan kurangnya keinginan murid dalam menjawab pertanyaan ketika pembelajaran dikelas. Selain itu, Yunani (2015) juga menemukan beberapa masalah dalam pembelajaran PAI. Masalah tersebut adalah pembelajaran agama islam masih berjalan monoton, belum ditemukan strategi belajar yang tepat, rendahnya hasil belajar siswa di SD Negeri 103 Palembang, dan rendahnya motivasi belajar siswa untuk mengikuti proses pembelajaran. Selain itu, Nur'suadah (2016) dan Kunar (2016) juga menemukan masalah yang sama yaitu rendahnya hasil belajar siswa pada mata pelajaran Pendidikan Agama Islam.

Guru SDN. No. 026/XI Cempaka juga menemukan masalah rendahnya hasil belajar pada mata pelajaran Pendidikan Agama Islam di kelas V SDN. No. 026/XI Cempaka tahun 2016/2017. Hasil belajar yang diperoleh siswa termasuk dalam kategori rendah dan tidak memenuhi KKM kompetensi dasar yang telah ditetapkan. Nilai rata-rata kelas yang diperoleh oleh delapan orang siswa kelas V SDN. No. 026/XI Cempaka tahun 2016/2017 adalah 53,13 dengan ketuntasan belajar sebesar $37,50 \%$. Hasil ini menunjukkan bahwa hanya ada tiga orang siswa yang memenuhi Kriteria Ketuntasan Minimun (KKM) kompetensi dasar untuk 
mata pelajaran Pendidikan Agama Islam. Menurut Winkel (2009), hasil belajar menjadi bukti keberhasilan yang telah dicapai oleh seseorang yang belajar. Hasil belajar yang rendah mengindikasikan bahwa tujuan pembelajaran tidak tercapai.

Selain melalui tes, guru mencoba menganalisis masalah dengan menggunakan metode pengamatan/observasi. Hasil observasi menunjukkan bahwa guru menggunakan model pembelajaran yang kurang tepat. Guru mengajar dengan menggunakan metode konvensional, seperti ceramah, Tanya jawab, dan pemberian tugas. Hasilnya, siswa merasa pembelajaran menjadi tidak menarik yang mendorong perilaku negatif lainnya, seperti: mengobrol dengan teman, mengabaikan penjelasan guru, men-coret-coret di buku catatan, memainkan alat tulis, dan termenung. Masalah ini harus dipecahkan agar tujuan pembelajaran dapat tercapai.

Langkah yang dipilih adalah memperbaiki model pembelajaran. Suprihatiningrum (2014) mengartikan model pembelajaran sebagai pola yang telah direncanakan dengan matang dan merupakan pedoman pelaksanaan pembelajar-an mulai dari kegiatan pembuka, inti, penutup, serta penilaian pembelajaran yang disusun sedemikian rupa untuk mencapai tujuan pembelajaran. Salah satu contoh model pembelajaran adalah model pembelajaran kooperatif. Pembelajaran kooperatif mengacu pada metode pembelajaran, yang mana siswa bekerja bersama dalam kelompok kecil saling membantu dalam belajar (Suprihatiningrum, 2014).

Salah satu model pembelajaran yang dapat digunakan untuk menjawab permasalahan di atas antara lain dengan menerapkan model pembelajaran kooperatif tipe Student Team Achievement Division (STAD). Pembelajaran kooperatif dapat juga diartikan sebagai suatu variasi metode pembelajaran di mana siswa bekerja dalam kelompok kecil untuk saling membantu dalam mempelajari materi akademis (Slavin, 2005). Model pembelajaran kooperatif tipe Student Team Achievement Division (STAD) menempatkan siswa dalam kelompok- kelompok yang heterogen untuk saling membantu satu sama lain dalam belajar dengan menggunakan berbagai metode pembelajaran kooperatif dan prosedur kuis. Model pembelajaran kooperatif tipe Student Team Achievement Division (STAD) melibatkan pengakuan kelompok dan tanggung jawab kelompok untuk pembelajaran individu anggota kelompok.

Model pembelajaran Student Teams Achievement Division (STAD) dianggap cara yang tepat untuk meningkatkan kemampuan membaca pemahaman pada siswa karena gagasan utama dari Model pembelajaran Student Teams Achievement Division (STAD) adalah untuk memotivasi para siswa untuk mendorong dan membantu satu sama lain untuk menguasai keterampilan-keterampilan yang disajikan oleh guru (Slavin, 2005). Jika para siswa menginginkan agar kelompok mereka memperoleh penghargaan, mereka harus membantu teman sekelompoknya untuk mempelajari materi yang diberikan. Mereka harus mendorong teman mereka untuk melakukan yang terbaik dan menyatakan suatu norma bahwa belajar itu merupakan suatu yang penting, berharga, dan menyenangkan.

Menurut lbrahim, dkk (2006), Model pembelajaran Student Teams Achievement Division (STAD) memiliki kelebihan beberapa kelebihan yang berguna dalam kegiatan pembelajaran. Pertama, STAD relatif mudah menyelenggarakannya, mampu memotivasi siswa dalam mengembangkan potensi individu terutama kreativitas dan tanggung jawab dalam mengangkat citra kelompoknya. Kedua, STAD melatih siswa untuk bekerja sama dan saling tolong menolong dalam kelompok. Ketiga, siswa lebih mampu berkomunikasi verbal dan nonverbal dalam bekerja sama. Keempat, siswa mampu meyakinkan dirinya dan orang lain bahwa tujuan yang ingin dicapai bergantung pada kinerja mereka, bukanlah karena keberuntungan. Kelima, model ini juga dapat meningkatkan keakraban siswa. Dengan demikian, penggunaan model pembelajaran kooperatif tipe STAD diharapkan dapat meningkatkan aktivitas siswa dalam proses pembelajaran. Peningkatan aktivitas belajar siswa diharapkan juga dapat mendorong peningkatan hasil belajar siswa.

\section{METODE PENELITIAN}

Penelitian ini merupakan penelitian tindakan kelas. Penelitian dilakukan di SDN. No. 026/XI Cempaka, Kecamatan Hamparan Rawang, Kota Sungai Penuh, Provinsi Jambi. Kegiatan penelitian terdiri atas penyusunan proposal penelitian, pengumpulan data, pengolahan data, analisis data, dan penyusunan laporan. Penelitian dilakukan sejak bulan Januari sampai dengan bulan April tahun 2017.

Subjek dalam penelitian ini adalah siswa kelas $\mathrm{V}$ semester 2 tahun 2016/2017 di SDN. No. 026/XI Cempaka, Kecamatan Hamparan Rawang, Kota Sungai Penuh, Provinsi Jambi. Penelitian ini melibatkan 8 orang siswa. Selanjutnya, objek dalam penelitian ini adalah peningkatan hasil belajar siswa kelas $\mathrm{V}$ semester 2 tahun 2016/2017 di SDN. No. 026/XI Cempaka, Kecamatan Hamparan Rawang pada mata pelajaran Pendidikan Agama Islam, khususnya pada materi mengenal rasul-rasul Allah SWT.

Data yang dikumpulkan dalam penelitian tindakan kelas ini adalah data hasil belajar siswa. Hasil belajar siswa diperoleh melalui evaluasi jenis tes dan non-tes. Tes merupakan guru melakukan pengukuran terhadap hasil belajar siswa dengan cara memberikan pertanyaan-pertanyaan yang harus dijawab atau perintah-perintah yang harus dijalankan oleh siswa dan selanjutnya guru menilai hasil pengukuran yang diperoleh oleh setiap siswa. Dalam penelitian ini, evaluasi hasil belajar jenis nontes yang digunakan adalah pengamatan atau observasi. Guru mengamati aktivitas belajar siswa selama kegiatan pembelajaran berlangsung.

Penelitian tindakan kelas ini dilaksanakan dalam dua siklus yaitu siklus I dan siklus II. Setiap siklus dilakukan sebanyak dua kali pertemuan. Masing-masing siklus terdiri atas empat kegiatan, yaitu perencanaan, pelaksanakan, pengamatan, dan refleksi.

Data yang telah dikumpulkan diolah dan dianalisis dengan uji statistik sederhana. Uji statistik yang 
digunakan adalah penghitungan nilai rata-rata hasil belajar siswa dan persentase ketuntasan belajar siswa. Selanjutnya, nilai rata-rata dan persentase ketuntasan belajar siswa yang diperoleh dibandingkan antara sebelum dan sesudah tindakan.

Indikator keberhasilan dari penelitian tindakan kelas ini adalah peningkatan hasil belajar siswa pada mata pelajaran pendidikan Agama Islam di kelas $V$ SDN. No. 026/XI Cempaka tahun 2016/2017. Hasil belajar yang diperoleh setiap siswa dibandingkan dengan Kriteria Ketuntasan Minimum (KKM) kompetensi dasar mata pelajaran Pendidikan Agama Islam yang telah ditentukan oleh sekolah diawal tahun pelajaran 2016/2017 yaitu sebesar 60,00.

\section{HASIL DAN PEMBAHASAN Kondisi Pratindakan}

Sebelum memberikan tindakan, guru mengadakan tes penjajakan terlebih dahulu pada siswa. Tabel 1 memperlihatkan hasil belajar delapan orang siswa kelas V SDN. No. 026/XI Cempaka tahun 2016/2017 pada mata pelajaran Pendidikan Agama Islam sebelum diberi tindakan. Berdasarkan Tabel 1, nilai yang diperoleh siswa berada pada rentang 40,0065,00 . Nilai terendah yang diperoleh siswa adalah 40,00 dan nilai tertinggi yang diperoleh siswa adalah 70,00. Nilai rata-rata yang diperoleh adalah 53,13. Ada tiga orang siswa yang memiliki nilai yang memenuhi KKM kompetensi dasar, yaitu Gibran Dzaki, Marsa Afianda, dan M. Haykal. Guru juga malakukan penghitungan persentase ketuntasan belajar siswa. Hasil penelitian menunjukkan bahwa ketuntasan belajar siswa sebesar $37,50 \%$. Berdasarkan hasil tersebut, hasil belajar yang diperoleh siswa termasuk dalam kategori rendah dan juga hanya sedikit siswa yang memperoleh nilai yang memenuhi KKM kompetensi dasar yang telah ditetapkan yaitu 60,00 .

Tabel 1. Hasil tes penjajakan

\begin{tabular}{clccl}
\hline No & \multicolumn{1}{c}{ Nama Siswa } & KKM & Nilai & Keterangan \\
\hline 1 & Ahmad Bapadol & 60,00 & 50,00 & Tidak Tuntas \\
2 & Gibran Dzaki & 60,00 & 60,00 & Tuntas \\
3 & Marsa Afianda & 60,00 & 65,00 & Tuntas \\
4 & M. Akil Mubaraq & 60,00 & 55,00 & Tidak Tuntas \\
5 & M. Haykal & 60,00 & 60,00 & Tuntas \\
6 & M. Rifki & 60,00 & 50,00 & Tidak Tuntas \\
7 & Sasspa Tri Wahyuni & 60,00 & 45,00 & Tidak Tuntas \\
8 & Zethi Ramadhani Pratiwi & 60,00 & 40,00 & Tidak Tuntas \\
& Nilai Tertinggi & & 65,00 & \\
& Nilai Terendah & & 40,00 & \\
& Nilai Rata-Rata & & 53,13 & \\
& Ketuntasan Belajar & & $37,50 \%$ & \\
\hline
\end{tabular}

\section{Hasil Siklus I}

Kegiatan penelitian pada siklus I dilaksanakan pada hari Kamis, 2 Februari 2017 (Pertemuan ke-1 Siklus I), hari Kamis, 9 Februari 2017 (Pertemuan ke-2 Siklus I), dan hari Kamis, 16 Februari 2017 (Evaluasi Hasil Belajar Siklus I). Kegiatan penelitian pada siklus I terdiri atas perencanaan, pelaksanaan, pengamatan, dan refleksi.

Perencanaan. Kegiatan perencanaan terdiri atas: menyusun rencana pelaksanaan pembelajaran (rpp), menetapkan materi bahan ajar, merancang skenario pembelajaran, menyiapkan media pembelajaran, dan menyusun alat evaluasi hasil belajar

Penelitian tindakan kelas dilakukan pada pembelajaran Pendidikan Agama Islam pada materi Nama-Nama Rasul Allah SWT (Pertemuan ke-1) dan Firman Allah SWT tentang Rasul-Rasul Allah SWT (Pertemuan ke-2). Kegiatan dilaksanakan dalam tiga tahap yaitu kegiatan awal, kegiatan inti, dan kegiatan akhir.

Kegiatan awal, terdiri atas: Guru mengucapkan salam dan menanyakan keadaan siswa; Guru mengecek kehadiran siswa secara klasikal; Guru mengajak siswa secara bersama-sama membaca satu surat pendek dalam Al Qur'an; Guru menyampaikan tujuan pembelajaran; Guru menyampaikan skenario pembelajaran yang akan dilaksanakan.

Kegiatan inti, terdiri atas: siswa membentuk kelompok kecil yang terdiri atas 4 siswa yang heterogen; guru menyampaikan inti materi sebagai pengantar dan siswa menyimak penjelasan dari guru. Kemudian untuk lebih mendalami materi, siswa mengerjakan lembar kerja kelompok pada kegiatan diskusi kelompok; dan setelah memberikan pengantar materi guru memberikan lembar kerja kelompok yang harus didiskusikan pada masing-masing kelompok. Dengan diskusi siswa saling membantu dalam memahami materi. Masing-masing kelompok yang diwakili oleh satu atau dua anggota menyampaikan hasil diskusi kelompok di depan kelas.

Kegiatan penutup, terdiri atas:Guru mengevaluasi dengan memberikan kuis atau tes, dan melakukan penilaian terhadap hasil kerja kelompok; Guru memberikan penghargaan kepada kelompok yang memperoleh nilai tertinggi; Guru bersama siswa membuat kesimpulan pembelajaran; Guru menyampaikan gambaran materi pelajaran selanjutnya; Guru menyampaikan pesan moral.

Pengamatan. Hasil pengamatan aktivitas belajar siswa pada Siklus I disajikan pada Tabel 2. Secara umum, hasil pengamatan adalah sebagai berikut: siswa dapat mengikuti skenario pembelajaran; Siswa mendengarkan penjelasan guru; Kegiatan pembelajaran masih berpusat pada guru; Sebagian siswa belum mampu menjawab kuis; Sebagian siswa belum berani untuk melaporkan hasil ke depan kelas.

Tabel 2. Hasil pengamatan aktivitas belajar siswa pada akhir Siklus I

\begin{tabular}{clcc}
\hline No & \multicolumn{1}{c}{ Kriteria } & Jumlah & Persentase \\
\hline 1 & $\begin{array}{l}\text { Siswa mendengarkan penjelasan } \\
\text { guru }\end{array}$ & 8 & $100 \%$ \\
2 & $\begin{array}{l}\text { Siswa membentuk kelompok yang } \\
\text { heterogen }\end{array}$ & 8 & $100 \%$ \\
3 & $\begin{array}{l}\text { Siswa bekerja sama dalam } \\
\text { kelompok }\end{array}$ & 6 & $75 \%$ \\
4 & $\begin{array}{l}\text { Siswa dapat menjawab kuis } \\
\text { Siswa melaporkan hasil ke depan } \\
\text { kelas }\end{array}$ & 5 & $62,5 \%$ \\
& & $40 \%$ \\
\hline
\end{tabular}

Selanjutnya, hasil belajar siswa berdasarkan evaluasi hasil belajar jenis tes. Tes dilakukan dengan cara memberikan pertanyaan yang harus dijawab oleh siswa diakhir siklus I. Hasil belajar siswa pada evaluasi hasil belajar siklus I disajikan pada Tabel 3 . 
Tabel 3. Hasil penelitian pada Siklus I

\begin{tabular}{clcrl}
\hline No & \multicolumn{1}{c}{ Nama Siswa } & KKM & Nilai & Keterangan \\
\hline 1 & Ahmad Bapadol & 60,00 & 55,00 & Tidak Tuntas \\
2 & Gibran Dzaki & 60,00 & 75,00 & Tuntas \\
3 & Marsa Afianda & 60,00 & 80,00 & Tuntas \\
4 & M. Akil Mubaraq & 60,00 & 65,00 & Tuntas \\
5 & M. Haykal & 60,00 & 70,00 & Tuntas \\
6 & M. Rifki & 60,00 & 60,00 & Tuntas \\
7 & Sasspa Tri Wahyuni & 60,00 & 55,00 & Tidak Tuntas \\
8 & Zethi Ramadhani Pratiwi & 60,00 & 50,00 & Tidak Tuntas \\
& Nilai Tertinggi & & 80,00 & \\
& Nilai Terendah & & 50,00 & \\
& Nilai Rata-Rata & & 63,75 & \\
& Ketuntasan Belajar & & $62,50 \%$ & \\
\hline
\end{tabular}

Hasil penelitian yang disajikan pada Tabel 3 menunjukkan bahwa nilai terendah siswa pada akhir siklus I adalah sebesar 50 dan nilai tertinggi siswa adalah sebesar 80. Nilai rata-rata yang diperoleh delapan orang siswa adalah sebesar 63,75 . Nilai ratarata yang diperoleh siswa setelah diberikan tindakan yaitu penggunaan model pembelajaran kooperatif tipe STAD mengalami peningkatan dibandingkan dengan hasil tes penjajakan. Nilai rata-rata yang diperoleh siswa pada tes penjajakan sebesar 53,13. Setelah pelaksanaan Siklus I, nilai rata-rata siswa mengalami peningkatan sebesar 10,63 point menjadi 63,75. Ketuntasan belajar siswa juga mengalami peningkatan. Hasil evaluasi Siklus I menunjukkan bahwa ketuntasan belajar siswa yang awalnya adalah $37,50 \%$ pada hasil tes penjajakan meningkat menjadi $62,50 \%$ pada akhir Siklus I. Hasil ini mengindikasikan bahwa terjadi perubahan hasil belajar siswa kelas V SDN. No. 026/XI Cempaka setelah mengikuti pembelajaran yang menggunakan model pembelajaran kooperatif tipe STAD. Dengan demikian, penggunaan model pembelajaran kooperatif tipe STAD dalam kegiatan pembelajaran perlu dilanjutkan pada Siklus II. berikut:

Refleksi dari hasil penelitian adalah sebagai

1. Guru perlu melakukan perbaikan pada perangkat pembelajaran

2. Guru perlu mendampingi siswa dalam bekerja secara berkelompok

3. Guru perlu mengevaluasi pekerjaan siswa

4. Guru perlu memberikan motivasi pada siswa agar berani menyampaikan hasil pekerjaannya di depan kelas.

5. Guru merumuskan tindakan siklus II berdasarkan temuan pada siklus I.

\section{Hasil Siklus II}

Kegiatan penelitian pada siklus II dilaksanakan pada hari Kamis, 23 Februari 2017 (Pertemuan ke-1 Siklus II), hari Kamis, 2 Maret 2017 (Pertemuan ke-2 Siklus II), dan hari Kamis, 9 Maret 2017 (Evaluasi Hasil Belajar Siklus II). Kegiatan penelitian pada siklus II terdiri atas perencanaan, pelaksanaan, pengamatan, dan refleksi.

Kegiatan perencanaan terdiri atas: Menyusun Rencana Pelaksanaan Pembelajaran (RPP); menetapkan materi bahan ajar; merancang skenario pembelajaran; menyiapkan media pembelajaran; dan menyusun alat evaluasi hasil belajar.
Penelitian tindakan kelas dilakukan pada pembelajaran Pendidikan Agama Islam pada materi Rasul Ulul Azmi (Pertemuan ke-1) dan Perbedaan Nabi dan Rasul (Pertemuan ke-2). Kegiatan dilaksanakan dalam tiga tahap yaitu kegiatan awal, kegiatan inti, dan kegiatan akhir. Kegiatan awal, terdiri atas: Guru mengucapkan salam dan menanyakan keadaan siswa; Guru mengecek kehadiran siswa secara klasikal; Guru mengajak siswa secara bersama-sama membaca satu surat pendek dalam Al Qur'an; Guru menyampaikan tujuan pembelajaran; Guru menyampaikan skenario pembelajaran yang akan dilaksanakan. Kegiatan inti, terdiri atas: siswa membentuk kelompok kecil yang terdiri atas 4 siswa yang heterogen; guru menyampaikan inti materi sebagai pengantar dan siswa menyimak penjelasan dari guru. Kemudian untuk lebih mendalami materi, siswa mengerjakan lembar kerja kelompok pada kegiatan diskusi kelompok; dan setelah memberikan pengantar materi guru memberikan lembar kerja kelompok yang harus didiskusikan pada masing-masing kelompok. Dengan diskusi siswa saling membantu dalam memahami materi. Masing-masing kelompok yang diwakili oleh satu atau dua anggota menyampaikan hasil diskusi kelompok di depan kelas. Kegiatan penutup, terdiri atas:Guru mengevaluasi dengan memberikan kuis atau tes, dan melakukan penilaian terhadap hasil kerja kelompok; Guru memberikan penghargaan kepada kelompok yang memperoleh nilai tertinggi; Guru bersama siswa membuat kesimpulan pembelajaran; Guru menyampaikan gambaran materi pelajaran selanjutnya; Guru menyampaikan pesan moral.

Pada siklus II, aktivitas belajar siswa mengalami peningkatan dibandingkan dengan siklus sebelumnya. Peningkatan tersebut terjadi pada kemampuan siswa dalam melaporkan hasil ke depan kelas. Awalnya hanya ada empat orang siswa dari delapan siswa yang berani melaporkan pekerjaannya ke depan kelas. Namun, pada siklus II enam dari delapan siswa telah berani menyampaikan hasil pekerjaannya ke depan kelas. Kemampuan bekerjasama siswa dalam kelompok juga meningkat. Pada siklus II, seluruh siswa telah mampu bekerja sama dengan teman sekelompoknya. Peningkatan juga terjadi dalam hal kemampuan siswa menjawab kuis. Awalnya hanya ada lima orang siswa dari delapan siswa yang dapat menjawab kuis. Namun, pada siklus II tujuh dari delapan siswa telah mampu untuk menjawab kuis. Dengan demikian, guru hendaknya tetap terus memotivasi siswa untuk terlibat aktif dalam kegiatan pembelajaran dan juga memberikan penguatan kepada siswa untuk meningkatkan keberanian siswa.

Tabel 4. Hasil pengamatan aktivitas belajar siswa pada akhir Siklus II

\begin{tabular}{clcc}
\hline No & \multicolumn{1}{c}{ Kriteria } & Jumlah & Persentase \\
\hline 1 & Siswa mendengarkan penjelasan guru & 8 & $100 \%$ \\
2 & $\begin{array}{l}\text { Siswa membentuk kelompok yang } \\
\text { heterogen }\end{array}$ & 8 & $100 \%$ \\
3 & Siswa bekerja sama dalam kelompok & 8 & $100 \%$ \\
4 & Siswa dapat menjawab kuis & 7 & $82,5 \%$ \\
5 & $\begin{array}{l}\text { Siswa melaporkan hasil ke depan } \\
\text { kelas }\end{array}$ & 6 & $75 \%$ \\
\hline
\end{tabular}


Selanjutnya, hasil belajar siswa berdasarkan evaluasi hasil belajar jenis tes. Tes dilakukan dengan cara memberikan pertanyaan yang harus dijawab oleh siswa diakhir siklus II. Hasil belajar siswa pada evaluasi hasil belajar siklus II disajikan pada Tabel 5. Hasil penelitian menunjukkan bahwa nilai terendah siswa pada akhir siklus II adalah sebesar 60,00 dan nilai tertinggi siswa adalah sebesar 90,00. Nilai rata-rata yang diperoleh delapan orang siswa adalah sebesar 75,00 . Nilai rata-rata yang diperoleh siswa pada Siklus II mengalami peningkatan dibandingkan dengan hasil tes penjajakan dan juga hasil tes pada akhir siklus I. Nilai rata-rata yang diperoleh siswa pada tes penjajakan sebesar 53,13. Setelah pelaksanaan Siklus I, nilai ratarata siswa mengalami peningkatan sebesar 10,63 point menjadi 63,75. Setelah pelaksanaan Siklus II, nilai ratarata siswa kembali mengalami peningkatan menjadi 75,00 . Hasil yang sama juga ditemukan pada ketuntasan belajar siswa. Ketuntasan belajar siswa juga mengalami peningkatan. Hasil evaluasi Siklus I menunjukkan bahwa ketuntasan belajar siswa yang awalnya adalah $37,50 \%$ pada hasil tes penjajakan meningkat menjadi $62,50 \%$ pada akhir Siklus I dan kembali meningkat menjadi $100,00 \%$ pada akhir Siklus II. Hasil ini mengindikasikan bahwa terjadi perubahan hasil belajar siswa kelas $\mathrm{V}$ SDN. No. 026/XI Cempaka tahun 2016/2017 sebelum dan setelah diberikan tindakan. Dengan demikian, penggunaan model pembelajaran kooperatif tipe STAD berhasil meningkatkan hasil belajar siswa kelas V SDN. No. 026/XI Cempaka tahun 2016/2017.

Tabel 5 Hasil penelitian pada Siklus II

\begin{tabular}{clcrl}
\hline No & \multicolumn{1}{c}{ Nama Siswa } & KKM & Nilai & Keterangan \\
\hline 1 & Ahmad Bapadol & 60,00 & 65,00 & Tuntas \\
2 & Gibran Dzaki & 60,00 & 85,00 & Tuntas \\
3 & Marsa Afianda & 60,00 & 90,00 & Tuntas \\
4 & M. Akil Mubaraq & 60,00 & 75,00 & Tuntas \\
5 & M. Haykal & 60,00 & 85,00 & Tuntas \\
6 & M. Rifki & 60,00 & 75,00 & Tuntas \\
7 & Sasspa Tri Wahyuni & 60,00 & 65,00 & Tuntas \\
8 & Zethi Ramadhani Pratiwi & 60,00 & 60,00 & Tuntas \\
& Nilai Tertinggi & & 90,00 & \\
& Nilai Terendah & & 60,00 & \\
& Nilai Rata-Rata & & 75,00 & \\
& Ketuntasan Belajar & & $100,00 \%$ & \\
& & & &
\end{tabular}

\section{Refleksi}

Secara umum, nilai yang diperoleh siswa telah memenuhi KKM kompetensi dasar. Guru akan menghentikan kegiatan penelitian pada siklus II. Guru harus terus berusaha untuk memperbaiki kualitas pembelajaran agar diperoleh hasil yang optimal. Guru perlu menggunakan metode pembelajaran yang variatif dan inovatif sebagai upaya untuk meningkatkan partisipasi aktif siswa dalam kegiatan pembelajaran. Guru perlu membimbing siswa dalam memahami bahan bacaan. Hasil penelitian ini menjadi dasar guru dalam menyusun perencanaan untuk pembelajaran selanjutnya.

\section{Analisis Hasil Belajar Siswa}

Belajar dapat diartikan sebagai sebuah aktivitas untuk memperoleh pengetahuan, meningkatkan keterampilan, memperbaiki perilaku, sikap, dan mengukuhkan kepribadian (Sugiyono dan Hariyanto, 2011). Belajar juga didefinisikan sebagai sebuah proses yang dilakukan oleh individu untuk memperoleh pengetahuan dan pengalaman baru yang diwujudkan dalam bentuk perubahan tingkah laku yang relatif permanen dan menetap disebabkan adanya interaksi individu dengan lingkungan belajarnya (Irham dan Wiyani, 2013). Dengan demikian, belajar merupakan sebuah proses untuk meningkatkan pengetahuan, keterampilan, dan juga sikap.

Menurut Slameto (2010), hasil belajar dipengaruhi oleh faktor internal dan faktor eksternal. Faktor internal meliputi faktor jasmani (kesehatan dan cacat tubuh) dan juga psikologis (kecerdasan, perhatian, minat, bakat, motivasi, kematangan, dan kesiapan). Faktor eksternal meliputi faktor dari lingkungan keluarga, lingkungan sekolah, dan masyarakat.

Proses belajar dan mengajar memiliki tujuan-tujuan tertentu yang ingin dan harus dicapai. Baik atau buruknya suatu proses pembelajaran dapat diketahui dengan cara melakukan evaluasi hasil belajar pada siswa yang menjadi subjek utama dalam kegiatan pembelajaran. Menurut Irham dan Wiyani (2013), hasil evaluasi bermanfaat untuk memperbaiki proses yang belum berjalan dengan optimal, mengisi, serta melengkapi kekurangan yang muncul, dan mengembangkan proses yang dianggap sudah baik. Hasil belajar adalah tingkat penguasaan yang dicapai oleh pelajar dalam mengikuti proses belajar mengajar sesuai dengan tujuan pendidikan yang ditetapkan (Hamalik, 2003).

Hasil penelitian menunjukkan bahwa nilai yang diperoleh siswa baik dari segi nilai rata-rata maupun persentase ketuntasan belajar mengalami peningkatan. Nilai rata-rata siswa yang awalnya 53,13 meningkat menjadi 63,75 pada Siklus I, dan kembali meningkat menjadi 75,00 pada Siklus II. Demikian juga halnya dengan persentase ketuntasan belajar. Persentase ketuntasan belajar siswa yang awalnya $37,50 \%$ meningkat menjadi $62,50 \%$ pada Siklus I dan kembali meningkat menjadi $100,00 \%$ pada Siklus II. Rekapitulasi hasil belajar siswa pada saat pratindakan, siklus I, dan siklus II disajikan pada Gambar 1.

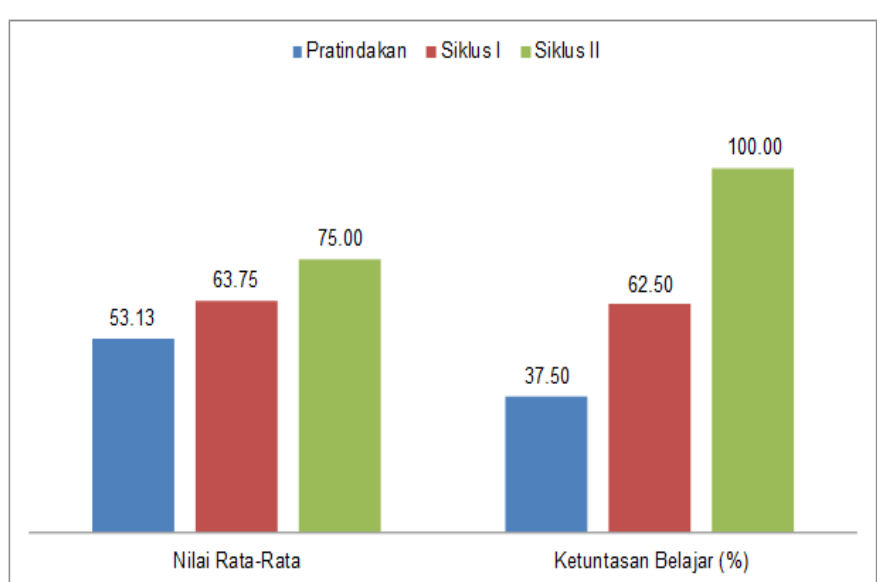

Gambar 1 Rekapitulasi hasil belajar siswa pada saat pratindakan, siklus I, dan siklus II 
Berdasarkan hasil penelitian, penggunaan model pembelajaran kooperatif tipe Student Team Achievement Division (STAD) dapat meningkatkan hasil belajar PAl siswa pada materi mengenal rasul-rasul Allah SWT di kelas V SDN. No. 026/XI Cempaka tahun 2016/2017. Hasil penelitian ini mendukung hasil penelitian sebelumnya bahwa model pembelajaran kooperatif tipe Student Team Achievement Division (STAD) dapat digunakan untuk meningkatkan hasil belajar siswa pada mata pelajaran Pendidikan Agama Islam. Hasil ini juga sesuai dengan temuan Jamiati (2011) bahwa model pembelajaran kooperatif tipe STAD dapat meningkatkan hasil belajar pendidikan agama islam pada siswa kelas IV Sekolah Dasar Negeri 040 Salo Kecamatan Salo. Hasil penelitian ini juga menguatkan hasil penelitian Kunar (2016) bahwa model kooperatif tipe STAD dapat meningkatkan motivasi belajar siswa pada mata pelajaran pendidikan agama islam kelas IV SDN 01 Luhak Nan Duo. Dengan demikian, model pembelajaran kooperatif tipe Student Team Achievement Division (STAD) dapat menjadi pilihan untuk guru dalam meningkatkan hasil belajar siswa mata pelajaran Pendidikan Agama Islam, khususnya pada materi mengenal rasul-rasul Allah SWT.

\section{SIMPULAN}

Penggunaan model pembelajaran kooperatif tipe Student Team Achievement Division (STAD) dapat meningkatkan hasil belajar siswa kelas V SDN. No. 026/XI Cempaka tahun 2016/2017 pada mata pelajaran PAI, khususnya materi mengenal rasul-rasul Allah SWT. $\mathrm{Hal}$ ini terlihat dari peningkatan nilai rata-rata dan persentase ketntasan belajar siswa. Nilai rata-rata siswa yang awalnya 53,13 meningkat menjadi 63,75 pada Siklus I, dan kembali meningkat menjadi 75,00 pada Siklus II. Persentase ketuntasan belajar siswa meningkat yang awalnya $37,50 \%$ meningkat menjadi $62,50 \%$ pada Siklus I dan kembali meningkat menjadi $100,00 \%$ pada Siklus II. Berdasarkan hasil penelitian, guru sebaiknya meningkatkan pengetahuan dan keterampilan dalam merencanakan kegiatan pembelajaran, melaksanakan kegiatan pembelajaran, menilai hasil pembelajaran, dan juga mengembangkan perangkat pembelajaran. Guru juga sebaiknya menggunakan metode, model, strategi, ataupun teknik yang digunakan hendaknya bervariasi.

\section{DAFTAR PUSTAKA}

Hamalik, O. (2004). Psikologi Belajar Mengajar. Bandung: Sinar Baru Algensindo.

Ibrahim, dkk. (2006). Pembelajaran Kooperatif. Surabaya: PSMS UNESA.

Irham, M., \& Wiyani, N. A. (2013). Psikologi Pendidikan: Teori dan Aplikasi dalam Proses Pembelajaran. Yogyakarta: Ar Ruzz Media.

Jamiati. (2011). Peningkatan Hasil Belajar Pendidikan Agama Islam Melalui Model Pembelajaran Kooperatif Tipe Student Teams Achievement (Stad) Siswa Kelas Iv Sekolah Dasar Negeri 040 Salo Kecamatan Salo [Skripsi thesis]. Riau: Universitas Islam Negeri Sultan Sarif Kasim Riau.
Kunar, B. (2016). Peningkatan Motivasi Belajar Siswa Melalui Model Kooperatif Tipe STAD Pada Mata Pelajaran Pendidikan Agama Islam Kelas IV SDN 01 Luhak Nan Duo. Jurnal Manajemen Pendidikan, 1(1).

Nursaadah. (2016). Meningkatkan Hasil Belajar Pendidikan Agama Islam (PAI) melalui Teknik Make A Match pada Siswa Kelas III SD Inpres Bumi Bahari. Jurnal Kreatif Tadulako Online, 4(8).

Slameto. (2010). Belajar dan faktor-faktor yang mempengaruhi. Jakarta: Rineka cipta.

Slavin, R. E. (2005). Cooperative Learning Teori, Riset, dan Praktik. Jakarta: Nusa Media.

Sugiyono \& Hariyanto. (2011). Belajar dan Pembelajaran: Teori dan Konsep Dasar. Bandung: Remaja Rosdakarya.

Suprihatiningrum, J. (2014). Strategi Pembelajaran: Teori dan Aplikasi. Yogyakarta: Ar Ruzz Media.

Yunani. (2015). Upaya meningkatkan hasil belajar siswa pada mata pelajaran PAI dalam mengenal malaikat dan tugasnya melalui metode make a match di kelas IV SD Negeri 103 Palembang. Palembang: Fakultas Tarbiyah dan Keguruan, Universitas Islam Negeri Raden Patah Palembang.

Winkel, W. S. (2009). Psikologi pengajaran. Yogyakarta: Media abadi. 